\title{
PENGEMBANGAN PAPAN FLANEL BERMAIN POLA UNTUK ANAK KELOMPOK B DI TK PERMATA BUNDA PALEMBANG
}

\author{
Renny Pramitha, Syafdaningsih, Sri Sumarni \\ Program Studi Pendidikan Guru Pendidikan Anak Usia Dini, \\ Fakultas Keguruan dan Ilmu Pendidikan, Universitas Sriwijaya \\ e-mail: rennipramitaaa@gmail.co.id
}

\begin{abstract}
Abstrak
Pengembangan papan flanel bermain pola untuk anak kelompok B di TK Permata Bunda Palembang telah dilakukan dengan tujuan untuk menghasilkan alat permainan papan flanel bermain pola yang valid dan praktis untuk anak kelompok B. Pengembangan dilakukan dengan menggunakan model Rowntree mencakup perencanaan, pengembangan, evaluasi. Teknik mengumpulkan data menggunakan metode wawancara, walkthrough, observasi. Pada tahap evaluasi dilakukan evaluasi formatif yang dilakukan oleh Tessmer, yaitu tahap self evaluation, expert review diperoleh nilai rata-rata dari para ahli sebesar 3,67 kategori sangat valid karena materi sesuai dengan indikator yaitu materi bermain pola yang sesuai dengan perkembangan kognitif anak kelompok B. Dari segi media juga sesuai dengan indikator yaitu bahan yang efektif dan efisien, desain tampilan, estetika. One-toone dan small evaluation bertujuan untuk melihat kepraktisan ialah praktis jika para pakar dan praktisi menyatakan bahwa produk yang dikembangkan dapat diterapkan. Hasil tahap one-to-one evaluation dan small group evaluation dengan indikator mampu mengenal bentuk buah, mengenal konsep warna dan mengenal konsep pola diperoleh nilai rata-rata sebesar $87 \%$ kategori sangat praktis. Praktis artinya papan flanel bermain pola menarik minat anak dalam mengenal konsep pola melalui metode bermain. Kelemahan dari produk ini adalah memerlukan biaya yang besar untuk membuatnya dan sukar menempel pada benda yang berat. Untuk peneliti selanjutnya harus lebih mengembangkan papan flanel bermain pola yang dibuat dengan biaya yang murah dan memiliki daya rekat yang lebih kuat agar dapat menempelkan benda yang berat.
\end{abstract}

Kata Kunci: pengembangan papan flanel, bermain pola, anak kelompok b

\begin{abstract}
The development of the flannel board playing pattern for the children of group B in TK Permata Bunda Palembang has been carried out with the aim to produce a flannel board game to play a valid and practical pattern for children in group B. Development carried out using the Rowntree model includes planning, development, evaluation. The technique of collecting data using interview methods, walkthroughs, observations. In the evaluation phase formative evaluation was carried out by Tessmer, namely the self evaluation stage, expert review obtained the average value of the experts at 3.67 categories is very valid because the material is in accordance with the indicator that is the material playing patterns that are in accordance with the cognitive development of group B children In terms of media, it is also in accordance with the indicators, namely effective and efficient ingredients, display design, aesthetics. One-to-one and small evaluation aims to see practicality is practical if experts and practitioners state that the product being developed can be applied. The results of the one-to-one evaluation stage and small group evaluation with indicators able to recognize the shape of the fruit, recognize the concept of color and recognize the concept of patterns obtained an average value of $87 \%$ very practical categories. Practical means that the flannel board plays a pattern of interest in getting to know the concept of patterns through playing methods. The disadvantage of this product is
\end{abstract}


that it requires a large cost to make it difficult to attach to heavy objects. For the next researcher, they should develop a flannel board playing patterns that are made at a low cost and have a stronger adhesion to be able to attach heavy objects.

Keywords: flannel board development, playing patterns, group b children.

\section{PENDAHULUAN}

Anak setelah di lahirkan dari rahim ibu sampai dengan usia 8 tahun disebut sebagai Anak Usia Dini (AUD). Berdasarkan pendapat tersebut, pendidikan prasekolah di Indonesia dibagi menjadi beberapa program pendidikan yaitu Kelompok Bermain (KB) dan Taman Kanak-kanak (TK). TK tergolong anak usia dini dengan rentang usia 4-6 tahun dan dibagi menjadi dua kelompok sesuai dengan usianya yaitu Anak kelompok A berada pada rentang usia 4-5 tahun, sedangkan anak kelompok B berada pada rentang usia 5-6 tahun. Anak pada rentang usia tersebut sedang berada pada tahap pertumbuhan dan perkembangan. Perkembangan yang dicapai anak merupakan aspek-aspek pemahaman nilai agama dan moral, fisik, kognitif, bahasa, dan sosial emosional.

Peraturan pemerintah nomor 146 tahun 2014 tentang kurikulum 2013 anak usia dini 5-6 tahun memiliki indikator pencapaian perkembangan dapat melakukan kegiatan yang menunjukkan anak mampu mengenal benda dengan mengelompokkan berbagai benda di lingkungannya berdasarkan ukuran, pola, fungsi, sifat, suara, tekstur, fungsi, dan ciri-ciri lainnya. Menurut Bronson dalam Rachmawati (2016), anak usia 5-6 tahun memiliki kemampuan kognitif yaitu Menunjukkan ketertarikan pada aktivitas membuat pola.

Berdasarkan hasil wawancara dengan Ibu Arum selaku guru kelas B TK Permata Bunda mengungkapkan bahwa guru setuju apabila peneliti mengembangkan sebuah alat permainan tentang bermain pola. Karena pada materi pola TK Permata Bunda menggunakan lembar kerja peserta didik yang dirasa kurang menarik dan kurang bervariasi terhadap materi pola, Masalah yang dihadapi anak-anak di TK Permata Bunda Palembang pada saat melakukan kegiatan membuat pola pada lembar kerja peserta didik adalah anak kesulitan dalam menentukan bentuk selanjutnya. Sebagian anak mampu menentukan bentuk selanjutnya untuk membuat sebuah pola yang utuh tetapi sebagian besar anak di kelas tersebut kesulitan menentukan bentuk selanjutnya. Hal ini mungkin terjadi karena pembelajaran di TK diberikan hanya melalui lisan dan gambar, melainkan kurang adanya peran dari benda-benda real yang menunjang sesuai dengan teori belajar oleh Bruner.

Lebih lanjut peneliti melakukan survey ke TK Khalifah 23 Palembang yang berlokasi di Maskarebet yang memiliki jumlah siswa 20 orang perkelasnya. Setelah dilakukan proses wawancara pada Ibu Rima selaku guru di kelas kelompok B dan dalam jawabannya Ibu Rima mengungkapkan keantusiasannya terhadap alat permainan yang akan dikembangkan oleh peneliti. Dalam wawancara Ibu Rima mengatakan bahwa papan flanel bermain pola ini akan berguna bagi gurunya karena akan mempermudah guru dalam menyampaikan materi bermain pola. Ibu Rima juga mengatakan papan flanel ini dapat menarik minat anak dalam belajar bermain pola dan juga akan memudahkan guru dalam mengajarkan materi pola ini kepada anak. Kemudian, terakhir peneliti melakukan survey dan wawancara di TK Auladi yang berlokasi Perumnas Palembang. Hasil wawancara dengan Ibu Aisyah selaku guru yang mengajar di kelas kelompok B menyatakan guru memberikan respon positif apabila peneliti ingin mengembangkan Alat Permainan yang dapat berguna untuk 
memudahkan guru dalam mengenalkan konsep pola matematika pada anak kelompok B. Lalu Ibu Aisyah menyatakan menerima apabila peneliti akan mengembangkan Alat Permainan berupa papan flanel bermain pola dalam mengenalkan konsep pola matematika untuk anak kelompok B.

Berdasarkan latar belakang di atas peneliti ingin mengembangkan pengetahuan anak dalam mengenal pola hingga ke pola ABCDABCD. Tidak hanya pola yang sederhana melainkan juga pola yang lebih sulit bagi anak. Oleh karena itu, agar pelaksanaan pengembangan keterampilan anak dalam mengenal dan mengerti tentang konsep pola ABCD-ABCD sesuai dengan harapan maka penulis bermaksud melakukan pengembangan papan flanel bermain pola yang bertujuan untuk meningkatkan kemampuan anak khususnya dalam mengenal pola ABCDABCD. Sesuai dengan penelitian yang dilakukan oleh Marpirah, Demi Fadillah, Marmawi (2014) dengan judul "Kemampuan Mengenal Pola Abcd Dengan Media Gambar Di Taman Kanak-Kanak Pgri Karya Nilam Ketapang” volume 3 No. 8 tahun 2014. Maka dari itu, peneliti tertarik untuk menindak lanjuti penelitian diatas dengan judul "Pengembangan Papan Flanel Bermain Pola untuk Anak Usia 5-6 Tahun”

\section{METODE PENELITIAN}

Jenis Penelitian

Jenis penelitian yang di ambil oleh peneliti adalah jenis penelitian pengembangan (Research and Development).

\section{Prosedur Penelitian}

Tahapan awal pada penelitian ini adalah tahapan pengkajian. Analisis kebutuhan merupakan kegiatan studi pendahuluan untuk mengetahui apakah produk yang akan diciptakan ini dibutuhkan oleh guru atau sekolah, serta apakah produk yang akan diciptakan ini sesuai dengan karakteristik dan indikator pencapaian perkembangan kognitif anak usia (4-5 tahun) dan mendeskripsikan kriteria media yang baik untuk anak berdasarkan tema semester 1 dan 2 sesuai dengan kurikulum 2013.

Sehingga peneliti melakukan observasi awal di TK Permata Bunda, TK Khalifah 23 Palembang, dan TK Auladi Sako Palembang dengan mengamati kegiatan belajar mengajar di TK tersebut dan melakukan wawancara bahwa memang benar produk yang akan diciptakan ini benar-benar dibutuhkan. Jika memang dibutuhkan barulah peneliti dapat menciptakan dan mengembangkan produk papan flanel bermain pola untuk anak kelompok B.

Pengembangan adalah proses mengembangkan perangkat produk yang diperlukan dalam pengembangan atau dengan kata lain berisi kegiatan realisasi rancangan produk. Berbasis pada rancangan produk, dan membuat instrumen untuk mengukur kinerja produk.

Peneliti memproduksi produk berupa media papan flanel bermain pola untuk anak kelompok B. Hasil keseluruhan tahap pengembangan ini adalah prototipe 1 . Pada tahap pengembangan juga disiapkan perangkat evaluasi yang digunakan untuk menilai papan flanel bermain pola yang telah dibuat dilihat dari segi materi dan media. Perangkat evaluasi berupa lembar validasi materi, media dan lembar observasi untuk menilai tingkah laku anak terhadap penggunaan papan flanel bermain pola.

\section{Evaluasi}

Pada tahap ini penilaian dilakukan oleh peneliti sendiri terhadap produk papan flanel telah dikembangkan. Disini peneliti mengevaluasi sendiri semua media dalam hal ini adalah dikembangkannya, apakah sesuai dengan kurikulum 2013, apakah sesuai dengan kebutuhan anak, apakah sesuai dengan kemampuan anak, apakah produk papan flanel menarik perhatian minat anak untuk belajar pola bilangan, apakah materinya sesuai dengan konsep 
matematika untuk anak usia (5-6 tahun), apakah produk papan flanel aman dan memenuhi syarat media.

Hasil media (Prototipe1) yang dikembangkan atas dasar self evaluation, diberikan kepada para ahli (expert) untuk divalidasi. Pada tahap ini, validator akan melihat dan mengevaluasi desain media yang telah dibuat. Uji validitas yang dilakukan adalah uji validitas content (materi) dan desain media. Hasil validasi yang berupa tanggapan/komentar dan saran-saran pada lembar validasi akan dijadikan dasar untuk merevisi produk lagu anak usia dini berbasis matematika (prototipe1).

Pada tahap ini, papan flanel bermain pola diujicobakan pada anak. Peneliti memilih tiga orang anak secara acak untuk mewakili populasi target. Anak tersebut diberikan pembelajaran dengan materi pada prototipe 1 yang sudah direvisi. Di akhir pembelajaran anak akan diwawancarai secara terstuktur yang diberikan peneliti untuk mengetahui tanggapan anak terhadap prototipe 1 yang digunakan. Hal ini dilakukan dengan tujuan untuk melihat kepraktisan media tersebut dari sudut pandang anak. Tanggapan-tanggapan anak pada wawancara tersebut akan dijadikan dasar untuk merevisi media (prototipe1) sehingga menghasilkan prototipe 2 .

Pada tahap ini prototipe 2 diujicobakan pada kelompok kecil anak yang terdiri dari 9 orang. Selanjutnya, anak diberikan pembelajaran dengan prototipe 2 yang sudah direvisi. Pada akhir pembelajaran, anak akan diwawancarai secara terstuktur yang diberikan peneliti untuk mengetahui tanggapan anak terhadap media (prototype 2) yang digunakan.

Teknik pengumpulan data yang digunakan dalam penelitian ini yaitu:

Walkthrough dikutip Rosidah (2017) adalah validasi data yang melibatkan beberapa ahli untuk mengevaluasi produk sebagai dasar untuk merevisi produk awal/prototipe 1 .
Instrumen pengumpul data pada teknik ini adalah dengan menggunakan lembar validasi yang diberikan kepada ahli atau validator. Data yang dikumpulkan pada lembar validasi ini adalah berupa tanggapan dan saran-saran yang menjadi dasar peneliti untuk melakukan revisi pada produk awal/prototipe. Data dari hasil validasi oleh ahli kemudian didiskusikan dengan ahli itu sendiri untuk mendapatkan kejelasan informasi hasil validasi produk, sehingga peneliti bisa menggunakan data hasil validasi tersebut sebagai acuan untuk merevisi produk/prototipe sampai dinyatakan layak untuk diujicobakan.

Observasi, menurut Sugiyono (2015: 203) Observasi digunakan untuk menilai tingkah laku dilihat dari keaktif anak pada kegiatan pembelajaran. Pada penelitian ini, untuk mendapatkan data observasi dilakukan dengan cara melihat dan menilai secara langsung aktivitas dan tingkah laku anak selama proses pembelajaran. Observasi dilakukan pada saat tahap oneto-one dan small group apakah sudah terlaksana dengan baik saat menggunakan papan flanel bermain pola tersebut.

Hasil walkthrough dengan ahli dianalisis secara deskriptif sebagai masukan untuk merevisi media. Masukan tersebut dituliskan pada lembar validasi. Lembar validasi yang diberikan kepada ahli dalam bentuk skala likert. Sugiyono (2015:135) Skala Likert dengan menggunakan empat kategori jawaban yaitu Sangat Baik (SB), Baik (B), Tidak Baik (TB), dan Sangat Tidak Baik (STB) seperti terlihat pada Tabel 3.4 berikut: Hasil validasi dari validator disajikan dalam bentuk tabel. Selanjutnya dicari rata-rata skor tersebut dengan menggunakan rumus sebagai berikut.

$$
\mathrm{x}=\sum
$$

(Sudjana, 2017: 109)

Ket :

$\mathrm{X}=$ Nilai rata-rata

$\Sigma=$ Jumlah nilai data

$\mathrm{N}$ = Banyaknya data 
Selanjutnya rata-rata yang didapatkan disesuaikan dengan kategori seperti yang terlihat pada Tabel 1 berikut ini.

Tabel 1. Kategori Tingkat Kevalidan

\begin{tabular}{|c|c|}
\hline Rata-Rata & Kategori \\
\hline $3,25-4,00$ & Sangat Valid \\
\hline $2,50-3,24$ & Valid \\
\hline $1,75-2,49$ & Tidak Valid \\
\hline $1,00-1,74$ & Sangat Tidak Valid \\
\hline
\end{tabular}

(Modifikasi dari Sugiyono, 2015)

Hasil observasi terhadap anak selama uji coba pada tahap one-to-one evaluation, small group evaluation digunakan untuk melihat tingkah laku anak pada saat proses pembelajaran menggunakan papan flanel bermain pola. Data hasil obsevasi disajikan dalam bentuk tabel, kemudian menghitung nilai hasil observasi dengan menggunakan rumus sebagai berikut.

$$
=\frac{\text { Skor Perolehan }}{\text { Skor Maksimal }} \times 100 \%
$$

(Sunarti \& Rahmawati, 2014: 191)

Setelah mendapatkan nilai, kemudian menentukan kriteria sesuai dengan nilai yang didapat.

Tabel 2. Kategori Nilai Hasil Observasi Anak Terhadap Penggunaan Papan Flanel Bermain Pola

\begin{tabular}{|c|c|}
\hline Skor (\%) & Kategori \\
\hline $80-100$ & Baik Sekali \\
\hline $70-79$ & Baik \\
\hline $60-69$ & Cukup \\
\hline$<60$ & Kurang \\
\hline
\end{tabular}

(Amirono \& Daryanto, 2016: 126)

Nilai observasi dikonversikan ke dalam kategori yang ditetapkan seperti pada tabel 3 di bawah ini :

Tabel 3. Kategori Nilai Hasil Observasi

Anak Terhadap Kepraktisan Papan Flanel Bermain Pola

\section{Persentase}

\begin{tabular}{|c|c|}
\hline & Skor \\
\hline $86 \%-100 \%$ & Sangat Praktis \\
\hline $76 \%-85 \%$ & Praktis \\
\hline $60 \%-75 \%$ & Cukup Praktis \\
\hline$<59 \%$ & Tidak Praktis \\
\hline
\end{tabular}

HASIL DAN PEMBAHASAN Hasil

Sebelum membuat produk papan flanel bermain pola peneliti terlebih dahulu membuat materi sesuai dengan Peraturan Menteri Pendidikan dan Kebudayaan Republik Indonesia Nomor 146 Tahun 2014 Tentang Kurikulum 2013 Pendidikan Anak Usia Dini yang berusia (5-6 tahun) pada ruang lingkup perkembangan kognitif. Indikator pencapaian perkembangan usia (5-6 tahun) dapat dilihat dari aspek perkembangan kognitif anak yaitu anak dapat: “a) anak mengelompokkan berbagai benda di lingkungannya berdasarkan ukuran, pola, fungsi, sifat, suara, tekstur, fungsi, dan ciri-ciri, b) anak mampu mengenal benda berdasarkan lima seriasi atau lebih, bentuk, ukuran, warna, atau jumlah melalui kegiatan mengurutkan benda, c) anak mampu mengenal konsep besarkecil, banyak-sedikit, panjang-pendek, berat-ringan, tinggi-rendah dengan mengukur menggunakan alat ukur tidak baku, d) Menyebutkan angka bila diperlihatkan lambang bilangannya, e) Menyebutkan jumlah benda dengan cara menghitung."

Materi dalam papan flanel bermain pola untuk anak kelompok B memuat pembelajaran dalam pengenalan konsep pola bilangan yang dibuat dalam bentuk media alat permainan dan dimainkan dengan cara menyusun item pola menjadi suatu susunan pola yang utuh. selanjutnya hal tersebut juga bertujuan agar anak bisa dengan mudah dalam memahami konsep pola, mulai dari pola yang sederhana menjadi pola yang lebih rumit bagi anak. 
Uji Validitas dilakukan untuk menguji tingkat kevalidan papan flanel bermain pola, dengan melibatkan 2 ahli yaitu ahli desain dan materi. Kedua validator mengijinkan uji coba produk setelah dilakukan revisi sesuai dengan saran-saran yang telah dilakukan. Setelah mendapatkan hasil validasi dari ahli materi dan media peneliti kemudian merekapitulasi hasil penilaian validator. Hasil rekapitulasi penilaian validator materi dan desain media dapat dilihat pada Tabel 4 berikut ini.

Tabel 4. Rekapitulasi Hasil Penilaian Validator

\begin{tabular}{|c|c|c|c|c|c|}
\hline \multirow{2}{*}{$\begin{array}{l}\mathbf{N} \\
\mathbf{0}\end{array}$} & \multirow{2}{*}{$\begin{array}{c}\text { Valid } \\
\text { asi }\end{array}$} & \multicolumn{4}{|c|}{ Rekapitulasi Nilai } \\
\hline & & $\begin{array}{l}\text { Indika } \\
\text { tor } 1\end{array}$ & $\begin{array}{c}\text { Indika } \\
\text { tor } 2\end{array}$ & $\begin{array}{l}\text { Indika } \\
\text { tor } 3\end{array}$ & $\begin{array}{l}\text { Indika } \\
\text { tor } 4\end{array}$ \\
\hline 1 & $\begin{array}{l}\text { Mater } \\
\text { i }\end{array}$ & 4.00 & 3.25 & 4.00 & 3.75 \\
\hline 2 & Media & 4.00 & 3.50 & 3.50 & 3.50 \\
\hline \multicolumn{2}{|c|}{ Rata-Rata } & 4.00 & 3,37 & 3.75 & 3.62 \\
\hline \multicolumn{2}{|c|}{ Jumlah } & \multicolumn{4}{|c|}{14.74} \\
\hline \multicolumn{2}{|c|}{$\begin{array}{l}\text { Hasil Nilai } \\
\text { Rata-Rata }\end{array}$} & \multicolumn{4}{|c|}{3.68} \\
\hline \multicolumn{2}{|c|}{ Kategori } & \multicolumn{4}{|c|}{ Sangat Valid } \\
\hline
\end{tabular}

didapatkan bahwa rekapitulasi hasil penilaian validasi expert review untuk aspek materi dan aspek media dengan nilai rata-rata sebesar 3,68 (kategori sangat valid). Hasil komentar validasi expert review dapat dilihat pada tabel 5 dibawah ini:

Tabel 5. Komentar Validator pada Tahap Expert Review

\begin{tabular}{|c|c|c|c|}
\hline No & Validator & Komentar & $\begin{array}{c}\text { Tanggapan } \\
\text { Peneliti }\end{array}$ \\
\hline 1 & $\begin{array}{c}\text { Validator } \\
1\end{array}$ & $\begin{array}{ll}\checkmark & \text { Sesuaika } \\
& \text { n dengan } \\
& \text { materi } \\
& \text { pembelaj } \\
\text { aran anak } & \text { kelompo } \\
& \text { k B } \\
\checkmark & \text { Ukuran } \\
& \text { pepaya } \\
\text { dan jeruk } & \\
\checkmark & \text { Perbaiki } \\
\text { gradasi }\end{array}$ & $\begin{array}{l}\text { Telah di } \\
\text { perbaiki }\end{array}$ \\
\hline
\end{tabular}

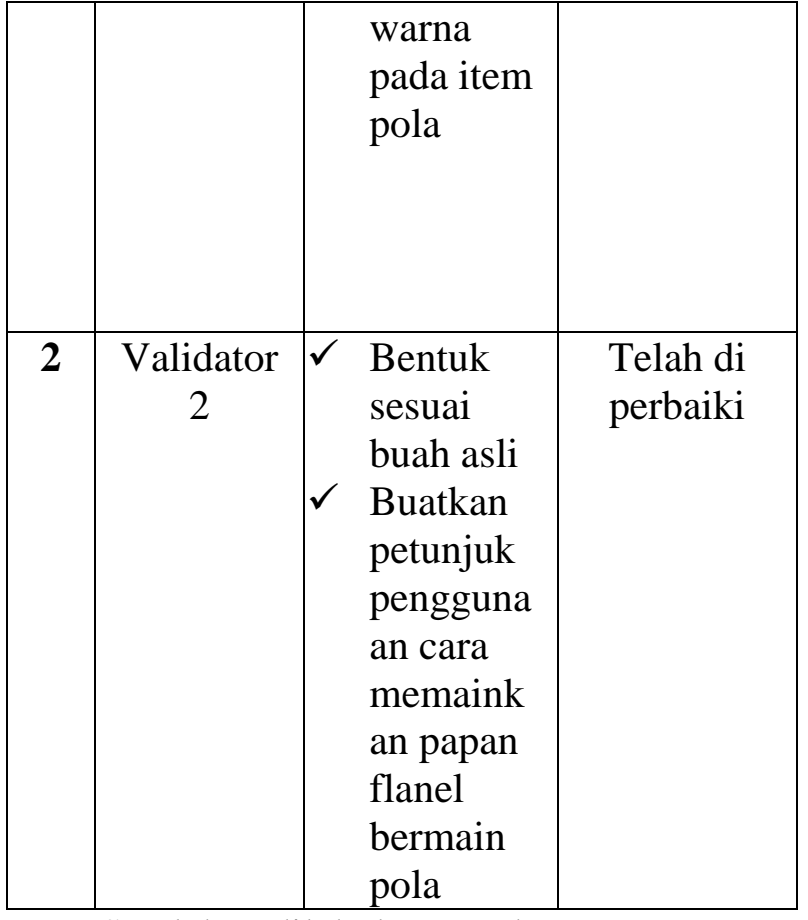

Setelah dilakukan tahap expert review terhadap prototipe 1 , selanjutnya dilakukan tahap one-to-one evaluation yang bertujuan untuk melihat kepraktisan prototipe 1 yang telah divalidasi oleh ahli. Menurut Kamus Besar Bahasa Indonesia (KBBI) dalam Poetra (2016:794) praktis adalah mudah dan senang memakainya (menjalankan dan sebagainya). Tahap ini melibatkan tiga orang anak

\section{Hasil Tahap One-to-one Evaluation}

Setelah dilakukan tahap expert review terhadap prototipe 1 , selanjutnya dilakukan tahap one-to-one evaluation yang bertujuan untuk melihat kepraktisan prototipe 1 yang telah divalidasi oleh ahli. Tahap ini melibatkan tiga orang anak dan mereka secara bersamaan menggunakan prototipe 1 . Pada saat proses pembelajaran menggunakan prototipe 1, mereka diobservasi oleh peneliti yang bertujuan untuk melihat dan menilai secara langsung aktivitas dan tingkah laku anak terhadap prorotipe 1. Data hasil observasi anak dapat dilihat pada Tabel 6 berikut ini.

Tabel 6. Hasil Rekapitulasi Analisis data Observasi Anak pada Tahap One-to-one Evaluation 


\begin{tabular}{|c|c|c|}
\hline 1 & MSI & 100 \\
\hline 2 & JA & 85 \\
\hline 3 & AD & 80 \\
\hline \multicolumn{2}{|c|}{ Jumlah } & $\mathbf{2 6 5}$ \\
\hline & Rata-rata (\%) & $\mathbf{8 8}$ \\
\hline \multicolumn{2}{c|}{ Kategori } & Sangat Praktis \\
\hline
\end{tabular}

Hasil analisis data observasi pada tahap one-to-one evaluation terhadap papan flanel bermain pola sebagai berikut: Muhammad Sultan Ibrahim mendapatkan skor dengan nilai 100, (2) Jihan Aqila mendapatkan skor dengan nilai 85 , (3) Angga Daniswara mendapatkan skor dengan nilai 80 . Jumlah total yaitu 265. Nilai persentase rata-rata sebesar $88 \%$ dengan kategori praktis. Papan Flanel Bermain Pola dalam kategori sangat praktis karena anak dapat mengenal benda berdasarkan bentuk, ukuran, dan warna melalui kegiatan mengelompokkan, mengenal konsep besar-kecil, banyak-sedikit, panjang-pendek, berat-ringan, tinggirendah, menyebutkan angka bila diperlihatkan lambang bilangannya, dan menyebutkan jumlah benda dengan cara menghitung. Sehingga dapat disimpulkan bahwa penggunaan lagu berbasis matematika memiliki kriteria praktis bagi anak. Kepraktisan baik sekali dalam artian media lagu sangat mudah digunakan dan dapat dinyanyikan berulang-ulang oleh anak.

\section{Hasil Tahap Small Group Evaluation}

Pada tahap small group evaluation, prototipe 2 diujicobakan kepada 9 orang anak secara kelompok. Pada akhir uji coba small group evaluation, anak diobservasi kembali keaktifannya terhadap 27prototipe 2 yang sedang dikembangkan. Hasil observasi anak terhadap penggunaan papan flanel bermain pola dapat dilihat pada Tabel 7 berikut ini.

\section{Tabel 7. Hasil Rekapitulasi Analisis Data Observasi pada Tahap Small GroupEvaluation}

\begin{tabular}{|c|c|c|}
\hline No & Nama Anak & Nilai Rata-Rata \\
\hline 1 & NA & 95 \\
\hline 2 & BK & 85 \\
\hline 3 & RAI & 75 \\
\hline
\end{tabular}

\begin{tabular}{|c|c|c|}
\hline 4 & MMR & 90 \\
\hline 5 & ZN & 80 \\
\hline 6 & DS & 85 \\
\hline 7 & KSK & 90 \\
\hline 8 & RRS & 80 \\
\hline 9 & MTWG & 95 \\
\hline \multicolumn{2}{|c|}{ Jumlah } & $\mathbf{7 7 5}$ \\
\hline \multicolumn{2}{|c|}{ Rata-rata (\%) } & $\mathbf{8 6}$ \\
\hline
\end{tabular}

Hasil analisis data observasi pada tahap small group evaluation terhadap papan flanel bermain pola sebagai berikut: (1) Nabillah Amanda mendapatkan nilai rata-rata sebesar 95 (2) Bella Kanaya mendapatkan nilai rata-rata sebesar 85 (3) Rameyza Alya Ibrahim mendapatlan nilai rata-rata sebesar 75 (4) Muhammad Michale Ramadhan mendapatkan nilai rata-rata sebesar 90 (5) Zarfa Nabillah mendapatkan nilai rata-rata sebesar 80 (6) Dwi Salsabila mendapatkan nilai rata-rata sebesar 85 (7) Khansa Shafiyah Khairunnisa mendapatkan nilai rata-rata sebesar 90 (8) Rashelia Rizky S mendapatkan nilai rata-rata sebesar 80 dan (9) Muhammad Tirta Wijaya Gumilang mendapatkan nilai rata-rata sebesar 95. Jumlah total yaitu 775 . Nilai persentase rata-rata sebesar $86 \%$ dengan kategori sangat praktis.

\section{Pembahasan}

Berdasarkan hasil analisis walkthrough didapatkan validitas materi sebesar 3,75 kategori sangat valid. Sangat valid artinya papan flanel bermain pola ini sudah sesuai dengan indikator kesesuaian materi pembelajaran matematika untuk anak kelompok B. anak usia dini 5-6 tahun memiliki indikator pencapaian perkembangan dapat melakukan kegiatan yang menunjukkan anak mampu mengenal benda dengan mengelompokkan berbagai benda di lingkungannya berdasarkan ukuran, pola, fungsi, sifat, suara, tekstur, fungsi, dan ciri-ciri lainnya. Anak usia 56 tahun memiliki kemampuan kognitif yaitu Menunjukkan ketertarikan pada aktivitas membuat pola. 
Selanjutnya hasil analisis validitas media papan flanel bermain pola didapatkan sebesar 3,60 dengan kategori sangat valid. Sangat valid artinya desain dari media papan flanel bermain pola telah sesuai dengan standar atau syarat untuk membuat media pembelajaran bagi anak, seperti media yang aman tidak membahayakan anak dan bahan yang mudah didapat. Dengan media pembelajaran yang menarik perhatian anak akan terpacu semangatnya untuk mempelajari materi pola. Kualitas produk yang di desain oleh peneliti sangat baik karena pada peneliti membuat produk sesuai dengan syarat media yang baik bagi anak.

Penelitian pengembangan ini berfokus untuk mengembangkan produk yang sesuai dengan salah satu tipe Richey, dkk (2018) dimana lebih menitik beratkan pada pengembangan produk itu sendiri. Sedangkan untuk tahap field test tidak dilakukan karena peneliti hanya mengembangkan produk dan tidak mengukur kemampuan dari subjek yang diteliti. Tujuan dari penelitian pada tahap self evaluation sampai small group evaluation untuk melihat kevalidan dan kepraktisan papan flanel bermain pola. Materi yang diuraikan telah disesuaikan untuk anak kelompok B. maateri dan media papan flanel yang di buat juga berdasarkan indikator dari Permendikbud Republik Indonesia Nomor 146 tahun 2014 tentang Kurikulum 2013 Pendidikan Anak Usia Dini. Dari keseluruhan pada tahap one-to-one evaluation didapatkan hasil nilai rata-rata sebesar 88 dengan kategori sangat praktis. Praktis sendiri berarti lagu berbasis matematika ini mudah dimainkan oleh anak dengan materi tidak terlalu sulit, kemudian media yang menarik bagi anak untuk mempelajarinya. Dengan metode bermain seperti ini, anak lebih cepat mengenal konsep pola bilangan untuk anak kelompok B. Senada dengan penelitian yang dilakukan oleh Setyawati Rahayu (2014) dengan judul "Upaya
Meningkatkan Kemampuan Mengenal Pola Abcd-Abcd Melalui Praktek Langsung Di Kelompok B Tk Pertiwi 54 Teruman, Bantul, Yogyakarta” Hasil penelitian menunjukkan bahwa kemampuan anak mengenal pola ABCDABCD dapat meningkat. Hal ini dapat diketahui dari meningkatnya kemampuan anak untuk mengenal pola $A B-A B$ berdasarkan persentase hasil observasi skor kemampuan anak dalam satu kelas pada kondisi pra tindakan diperoleh 89\% pada kriteria warna, $89 \%$ pada kriteria bentuk, dan $88 \%$ pada kriteria ukuran. Pada siklus I ditingkatkan dari pola AB$\mathrm{AB}$ ke pola $\mathrm{ABC}-\mathrm{ABC}$, kemudian ditingkatkan ke pola ABCD-ABCD pada siklus II. Berdasarkan hasil observasi yang diperoleh pada siklus I \& II menunjukkan persentase pada kriteria warna sebesar $83 \%$ menjadi $88 \%$, pada kriteria bentuk dari $87 \%$ menjadi $89 \%$, dan pada kriteria ukuran dari 84\% menjadi 89\%. Sedangkan berdasarkan persentase hasil penilaian dari skor kemampuan anak dalam satu kelas menggunakan portofolio pada siklus I \& II diperoleh hasil pada kriteria warna sebesar $86 \%$ hasilnya sama seperti pada siklus II. Pada kriteria bentuk menunjukkan persentase sebesar 88\% meningkat menjadi 91\%. Sedangkan pada kriteria ukuran, menunjukkan persentase sebesar $87 \%$ meningkat menjadi 91\%. Cara penerapan praktek langsung pada penelitian ini yaitu guru menyediakan alat dan bahan yang akan digunakan serta menjelaskannya; media yang digunakan pada setiap pola penyusunan pola tidak menggunakan media yang sama; anakanak menyusun pola dari yang sederhana ke yang lebih kompleks, yaitu dari pola $\mathrm{AB}-\mathrm{AB}, \mathrm{ABC}$ $A B C$, hingga ke pola $A B C D-A B C D$.

\section{KESIMPULAN}

Berdasarkan penelitian yang telah dilakukan tentang pengembangan papan flanel bermain pola dapat disimpulkan sebagai berikut. 
Papan flanel bermain pola yang dikembangkan dinyatakan sangat valid berdasarkan hasil validasi para ahli (expert review) yang terdiri dari ahli materi dan media sehingga papan flanel bermain pola ini layak digunakan sebagai media mengajar untuk pembelajaran matematika. Hal ini dapat diketahui dari rata-rata hasil expert review untuk aspek materi dan aspek media sebesar 3,68 (kategori sangat valid).

Sedangkan menguji kepraktisannya dilihat dari hasil observasi pada tahap oneto-one evaluation didapatkan hasil rata-rata pada ketiga anak sebesar 88 (kategori sangat praktis) dan pada tahap small group evaluation didapatkan hasil rata-rata pada ke sembilan anak sebesar 86 (kategori sangat praktis). Berdasarkan hasil validasi para ahli (expert review), one to one evaluation dan small group evaluation dapat dinyatakan bahwa papan flanel bermain pola untuk anak kelompok B yang dikembangkan telah teruji kevalidan dan kepraktisannya.

\section{UCAPAN TERIMA KASIH}

Penulis mengucapkan terima kasih kepada Ibu Dra. Syafdaningsih, M.Pd dan Dr. Sri Sumarni, M.Pd sebagai pembimbing atas segala bimbingan yang telah diberikan dalam penulisan jurnal ini. Penulis juga mengucapkan terima kasih kepada Bapak Prof. Sofendi, M.A., Ph.D., Dekan FKIP Unsri., Ibu Dr. Sri Sumarni, M.Pd., Ketua Jurusan Ilmu Pendidikan dan Ibu Dra. Syafdaningsih, M.Pd, Ketua Program Studi Pendidikan Guru Pendidikan Anak Usia Dini yang telah memberikan kemudahan dalam pengurusan administrasi penulisan jurnal ini. Lebih lanjut penulis juga mengucapkan terima kasih kepada DIKTI yang telah memberikan beasiswa pada beberapa semester pada saat penulis mengikuti pendidikan

\section{DAFTAR PUSTAKA}

Akker, J. 1999. Principle and metods of development research. In J Akker, R.
Branch, K. Gustalfon \& T. Nieveen dan Ploomp, Design Metodology and Development Research. Kluwer. London.

Gustafson, K.L dan Branch, R.M. 2002. Survey of Instructional Development Models. New York : Fourth editions. Syracuse:

Latif, Zukhairina, Zubaidah, \& Afandi. 2014. Orientasi Pendidikan Anak Usia Dini “ Teori dan Aplikasi”. Jakarta : Kencana Prenadamedia Grup

Masganti. 2015. Psikologi Anak Usia Dini Jilid 1. Medan : Perdana Publishing

Mardapi Djemari. 2017. Pengukuran, Penilaian dan Evaluasi Pendidikan. Yogyakarta: Parama Publishing

Mulyasa.2014.Manajemen PAUD. Bandung: PT Remaja Rosdakarya

Piaget, Jean \& Barbel Inhelder. 2014. Psikologi Anak. (Penerjemah: Miftahul Jannah). Yogyakarta: Pustaka Pelajar 